of 0.04 per cent in the naujaites to 0.2 per cent in the lujavrites (Gerasimovsky, 1969; see also Bailey et al., this report) and the bottom sediments of the fjord have contents of $200-1000 \mathrm{~g} / \mathrm{l}$. The province is thus very rich in zinc. The mechanism by which the very high amounts of dissolved zinc have been transferred to the sea water is not yet known. However, we consider that the sampling and analytical errors cannot alone explain the anomaly.

\title{
References
}

Bohse, H., Larsen, L. M., Rose-Hansen, J., Nielsen, C. O. \& Sørensen, H. 1975: Current research on the Ilímaussaq alkaline intrusion, South Greenland. Rapp. Grønlands geol. Unders. 75, 81-83.

Nielsen, C. O., Rose-Hansen, J. \& Sørensen, H. 1976: Environmental, geochemical and ecological studies in the region around the Ilímaussaq alkaline intrusion, South Greenland. Rapp. Grønlands geol. Unders. 80, 93-97.

Gerasimovsky, V. I. 1969: Geochemistry of the Ilimaussaq alkaline massif (South-West Greenland) (in Russian). Moskva: Nauka, 174 pp.

Rose-Hansen, J., Nielsen, C. O. \& Sørensen, H. (edit.) 1977: The Narssaq project. A geochemical-ecological research project. Progress report no. 1. The 1974 field season vol. I \& II. Inst. Petrology, Univ. Copenhagen, 122 pp.

J.R.-H.,

Institut for Petrologi, University of Copenhagen,

$\emptyset$ ster Voldgade 10,

1350 Copenhagen $K$.

\section{Gravity and rock densities in the Ilímaussaq area, South Greenland}

\section{René Forsberg and Kaare Lund Rasmussen}

Early gravity measurements in South Greenland (Kejlsø, 1958; J. Olsen, personal communication) indicated a large positive Bouger anomaly around Narssaq. Newer terrain-corrected gravity data obtained by the Geodetic Institute as part of regional surveys in the Julianehåb and Godthåb regions showed this anomaly to be approximately over the Ilímaussaq alkaline intrusion. The anomaly is interesting not only because of its size, but also due to the lack of similar anomalies over other Gardar intrusions, such as the Igaliko complex.

The sparse data available (fig. 29) show the residual anomaly is about +30 mgal and 'pulled' away from the centre of the intrusion towards the Narssaq gabbro complex.

To investigate the applicability of a detailed gravity survey for studying the structure of the Ilímaussaq intrusion, a knowledge of density contrast between the different rock types of the intrusion and surroundings is imperative. With this aim, a laboratory density determina- 


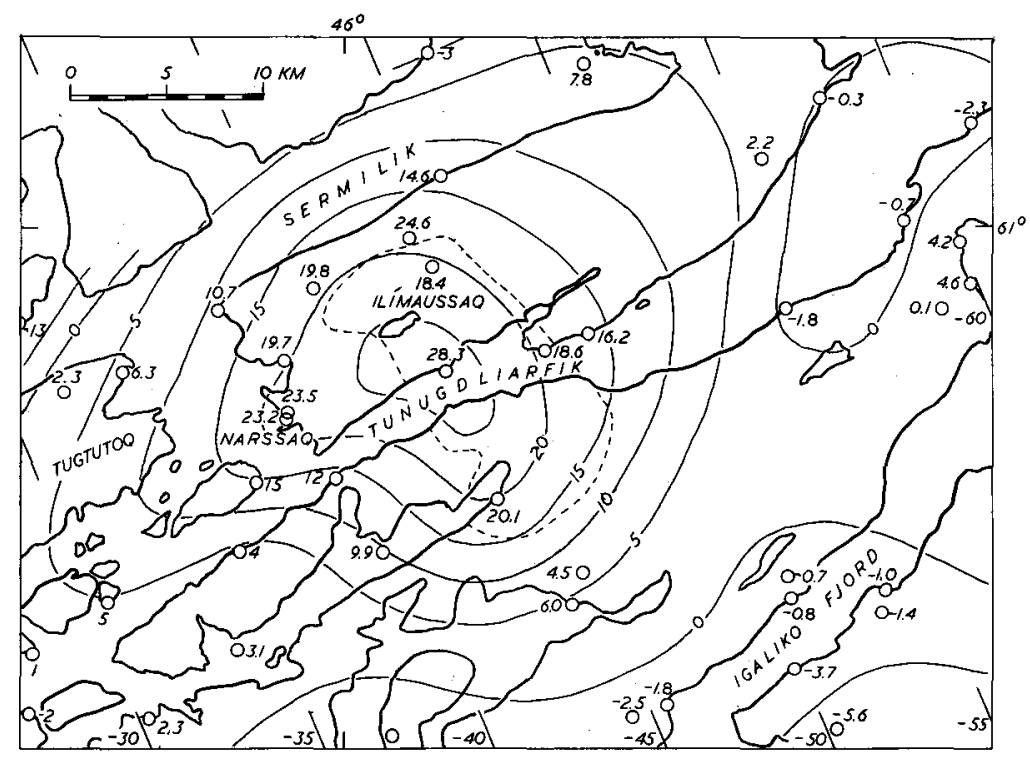

Fig. 29. Bouger anomaly map over the Ilímaussaq region, South Greenland.

tion programme has been undertaken in collaboration with the Institute of Petrology (University of Copenhagen) and GGU.

\section{Densities of the rocks of Ilimaussaq and surroundings}

For the different rock types investigated, a mean and a standard deviation $(\sigma)$ were determined (Table 6). Densities of the lighter and darker varieties of augite syenite fall in two distinct groups, and these were therefore treated as two separate rock types.

To see if the mean densities could be assumed to be the same for some rock types, a t-test was made between pairs of different rock types. Kakortokite was assumed to consist of white, red and black kakortokite in the ratio 0.78:0.13:0.09 (Bohse et al., 1971). Using a 95 per cent significance level some groupings were found which will be useful in the interpretation of gravity data, particularly since the contain the most widespread rocks of the area (Table 7).

\section{Preliminary interpretation}

Only the main trends in the structure can be inferred from the sparse data available at present.

An anomaly caused by the Ilímaussaq intrusion itself will be disturbed by the dense nearby Narssaq gabbros and the lava and sandstone of the down-faulted Narssaq peninsula. These two effects were removed by the use of a model of the lava sandstone thicknesses and a graphical smoothing. The model used assumed the thickness of the Eriksfjord Formation 
Table 6. Densities of rock types of the Ilimaussaq alkaline intrusion and surroundings, South Greenland

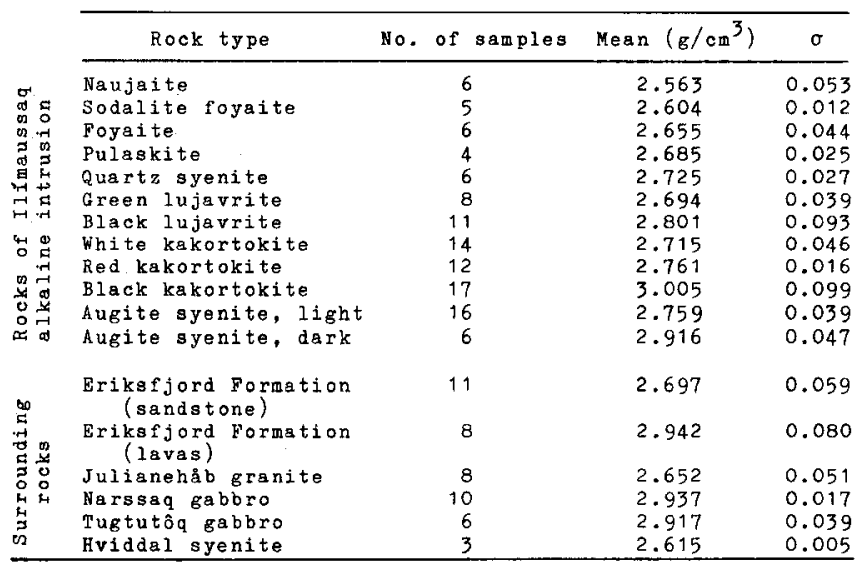

(Poulsen, 1964) to decrease from $2 \mathrm{~km}$ at Narssaq to 0 at the first basement outcrop to the NE. Using a 2:1 composition of sandstone and lava the model gravity anomaly is 6 to $7 \mathrm{mgal}$ in the northern part of the Ilimaussaq intrusion.

To interpret the remaining anomalies, various 3-dimensional prism models have been tested with the aid of a computer (Forsberg \& Rasmussen, 1977). These models gave the best fits when heavy bodies of density at least $2.9 \mathrm{~g} / \mathrm{cm}^{3}$ were placed with their tops at depths of $2-5 \mathrm{~km}$ and bottoms at a minimum depth of $20 \mathrm{~km}$, having vertical intrusion boundaries. It is therefore considered likely that a dense rock type not exposed at the surface of the intrusion underlies the Ilímaussaq intrusion.

\section{Conclusions}

The sparse gravity data from Ilímaussaq suggest that a dense body extending deep into the crust underlies the Ilímaussaq intrusion. A detailed gravimetric survey will yield valuable information on the deep structure of Ilímaussaq, but then the whole Narssaq peninsula and surroundings will have to be included in the survey and subsequent interpretation. A neces-

Table 7. Density groups of rocks of the Ilimaussaq alkaline intrusion and surrounding terrain, South Greenland

\begin{tabular}{lc}
\hline Rock types & Group mean $\mathrm{E} / \mathrm{cm}^{3}$ \\
\hline Naujaite & 2.56 \\
Julianeháb granite & 2.65 \\
Green lujavrite, sandstone & 2.70 \\
Kakortokite, light augite & \\
syenite, black lujavrite & 2.77 \\
Gabbros and lavas & 2.95 \\
\hline
\end{tabular}


sary tool for the data reduction is a detailed digital terrain model including bathymetric data from the fjords.

From gravimetry alone it will probably be impossible to distinguish between augite syenite and kakortokite, due to both the small density contrast and the unavoidable errors in the heights and topographic corrections for gravity stations in mountaneous areas. Thus to resolve the 'shallow' structure of Ilímaussaq, seismic control will be useful.

\section{Acknowledgements}

We would like to thank J. Olsen of the Geodetic Institute for putting the gravity data at our disposal, and to J. Rose-Hansen, Institute for Petrology, for collaboration in the project.

\section{References}

Bohse, H., Brooks, C. K. \& Kunzendorf, H. 1971: Field observations on the kakortokites of the Ilímaussaq intrusion, South Greenland, including mapping and analyses by portable X-ray fluorescence equipment for zirconium and niobium. Rapp. Grønlands geol. Unders. 38, $43 \mathrm{pp}$.

Ferguson, J. 1964: Geology of the Ilimaussaq alkaline intrusion, South Greenland. Description of map and structure. Bull. Grønlands geol. Unders. 39 (also Meddr Grønland 172, 4), $82 \mathrm{pp.}$

Forsberg, R. \& Rasmussen, K. L. 1977: Preliminary investigations on the densities and gravity in the Ilímaussaq area, South Greenland. Unpubl. rep., Inst. Geophysics, Univ. Copenhagen, 23 pp.

Kejlsø, E. 1958: Gravity measurements in Western Greenland 1950-52. Geodet. Inst. Skr. (3) 27, 69 pp.

Poulsen, V. 1964: The sandstones of the Precambrian Eriksfjord Formation in South Greenland. Rapp. Grønlands geol. Unders. 2, 16 pp.

Institut for Geofysik, University of Copenhagen,

Haraldsgade 6,

2200 Copenhagen $N$.

\section{Glaciological investigations in Johan Dahl Land, South Greenland, as a basis for hydroelectric power planning}

\section{Ole B. Olesen}

In 1973 GGU proposed a project for "delineating water resources in connection with hydroelectric power-plant possibilities along the west coast of Greenland" to Statens Naturvidenskabelige Forskningsråd (SNF, Danish National Science Research Council). The project consisted mainly of mapping all natural drainage basins situated on the ice-free west coast using available maps and aerial photographs. 